\title{
Classification of Weddell seal dives based on 3-dimensional movements and video-recorded observations
}

\author{
Randall W. Davis ${ }^{1, *}$, Lee A. Fuiman ${ }^{2}$, Terrie M. Williams ${ }^{3}$, Markus Horning ${ }^{1}$, \\ William Hagey ${ }^{4}$ \\ ${ }^{1}$ Department of Marine Biology, Texas A\&M University at Galveston, 5007 Avenue U, Galveston, Texas 77553, USA \\ ${ }^{2}$ Department of Marine Science, Marine Science Institute, University of Texas at Austin, 750 Channel View Drive, \\ Port Aransas, Texas 78373, USA \\ ${ }^{3}$ Department of Biology and Institute of Marine Science, University of California, Santa Cruz, California 95064, USA \\ ${ }^{4}$ Pisces Design, Avenida Mirola, La Jolla, California 92096, USA
}

\begin{abstract}
We classified Weddell seal Leptonychotes weddellii dives based on 58 spatial and temporal variables derived from 3-dimensional movements and assigned functions to the dive classifications based on video-recorded behavior. The variables were measured or calculated from data obtained by attaching a video and data recorder to the backs of 10 adult Weddell seals diving from an isolated ice hole in McMurdo Sound, Antarctica. Our analysis revealed 4 types of dives. Type 1 dives were intermediate in duration $(15.0 \pm 4.2 \mathrm{~min}$ ), deep (mean maximum depth $=378 \pm 93 \mathrm{~m}$ ) and had the steepest descent and ascent angles. Video recordings of the seals capturing prey, primarily small Antarctic silverfish Pleuragramma antarcticum, confirmed these were foraging dives. Types 2, 3 and 4 dives formed a continuum from very short, low speed, non-linear dives that were close to the hole (Type 2) to progressively longer, higher speed, very linear dives that ranged as much as $3 \mathrm{~km}$ from the hole (Type 4), but remained relatively shallow (<142 m) compared to Type 1 (foraging) dives. Type 2 dives were hypothesized to be related to hole-guarding behavior or the detection of other seals. Type 3 and 4 dives had characteristics suggestive of exploratory behavior. Comparisons with previously published dive classifications that were based on time-depth records showed that some functions attributed to certain dive types by previous researchers were correct, but others were not. This emphasizes the need for behavioral data for correct interpretation of dive profiles and time-depth statistics.
\end{abstract}

KEY WORDS: Weddell seal $\cdot$ Diving $\cdot$ Classification $\cdot$ Behavior $\cdot$ Foraging $\cdot$ Hunting

\section{INTRODUCTION}

The diving behavior of air-breathing vertebrates has been studied by direct observation and by analyzing a small number of spatial and temporal variables (e.g. dive depth and duration, rate of descent and ascent, time at depth, and swimming speed) of dives. Direct observation of diving behavior is limited by the rapid attenuation of light in water, the high swimming speeds of many animals, as well as the depth and duration of their dives. Animal-borne time-depth recorders (TDRs), satellite-linked time-depth recorders (SLTDRs) and acoustic tracking provide information on diving performance and underwater movements, but do not allow direct observation of animal behavior. Attempts have been made to classify and assign functions to dives based on depth and duration variables and the geometric shapes of depth-time profiles (Le Boeuf et al. 1988, 1992, 1993, Hindell et al. 1991, Bengston \& Stewart 1992, Asaga et al. 1994, Schreer \& Testa 1996, Crocker et al. 1997, Schreer et al. 2001, Baechler et al. 2002). In some cases, indirect evidence of feeding success (e.g. jaw movement, stomach temperature) has been available to identify foraging dives (Bjorge et al. 1995, Andrew 1998, Lesage et al. 1999, Plotz et al. 2001). A few investigators (Wartzok et al. 1992, 
Harcourt et al. 2000, Hindell et al. 2002) have used acoustic tracking techniques to examine the 3-dimensional movements of Weddell seals but did not classify dives or assign ecological functions. Acoustic tracking and dive classification based on 3-dimensional movements have been performed for free-ranging ringed seals Phoca hispida (Simpkins et al. 2001a-c). However, all of these studies are limited by the inability to associate diving characteristics with direct observations of animal behavior.

Weddell seals have been popular for the study of diving behavior because they make deep, long dives, and they are easy to capture to attach and recover recording instruments. Most of what we know about their diving behavior is based on data from TDRs, SLTDRs and acoustic telemeters (Kooyman 1968, Kooyman et al. 1980, Castellini et al. 1992, Wartzok et al. 1992, Testa 1994, Harcourt et al. 2000, Hindell et al. 2002) or, more recently, geomagnetic and acceleration recorders (Mitani et al. 2003). Kooyman $(1965,1968)$ described 3 basic dive patterns for Weddell seals diving from an isolated ice hole in McMurdo Sound, Antarctica, based on TDR data and observations from a sub-ice observation chamber. In his classification, Pattern I dives were short-duration ( $<5 \mathrm{~min})$, shallowdepth $(<100 \mathrm{~m})$ dives that were assumed to be associated with detection of other seals, assessment of under-ice conditions, resting or fighting with other seals. Pattern II dives were long-duration (>40 min) but relatively shallow dives $(<200 \mathrm{~m})$, in which the seal was assumed to explore the local area for other breathing holes. Pattern III dives were 300 to $400 \mathrm{~m}$ in depth, 8 to $15 \mathrm{~min}$ in duration, and had steep rates of descent and ascent. These were assumed to be hunting dives in which seals were feeding offshore on mid-water prey such as Antarctic silverfish and large toothfish Dissostichus mawsoni. More recently, Schreer \& Testa $(1995,1996)$ applied multivariate statistical techniques to TDR data to classify Weddell seal dives into 6 categories representing hypothesized functions such as pelagic foraging, benthic foraging, exploration and traveling.

Advances in the miniaturization of video and digital imaging technology have recently enabled researchers to use animal-borne instruments that record the in situ behavior of diving vertebrates and their prey and, in some cases, data on diving performance, locomotor activity and the physical environment (e.g. temperature and light intensity) (Marshall 1998, Davis et al. 1999, Ponganis et al. 2000, Heithaus et al. 2001, Bowen et al. 2002, Hooker et al. 2002, Parrish et al. 2002). We used an animal-borne video and data recorder to observe Weddell seal behavior at depth and collect simultaneous data to compute 3D movements. This enabled us to generate a large number of spatial and temporal variables with which to classify dives and, in some cases, to assign a function based on videorecorded behavior.

\section{MATERIALS AND METHODS}

The video system and data recorder were attached to the backs of 10 adult Weddell seals ( 9 males, 1 female; mean body mass $=379 \mathrm{~kg} \pm 36.3 \mathrm{SD}$; mean standard length $=239 \mathrm{~cm} \pm 9.6 \mathrm{SD}$ ) diving from an isolated ice hole in McMurdo Sound, Antarctica $\left(77.86^{\circ} \mathrm{S}\right.$, $166.22^{\circ} \mathrm{E}$ ) in November and December of 1998 and 1999. The video system and data recorder have previously been described (Davis et al. 1999). Briefly, the torpedo-shaped metal housing was $35 \mathrm{~cm}$ long, $13 \mathrm{~cm}$ in diameter and pressure-rated to a depth of $1000 \mathrm{~m}$. The low-light sensitive, monochrome video camera$6 \mathrm{~cm}$ long by $6 \mathrm{~cm}$ in diameter; minimum illumination $=$ 0.05 lux; angle of view $=80^{\circ}$ horizontal, $60^{\circ}$ vertical) (Model Y-1205, Marshall Electronics)—was encircled by an array of near-infrared light-emitting diodes (LEDs). These LEDs enabled the camera to record images in complete darkness to a distance of ca. $1 \mathrm{~m}$ or greater distances when additional ambient light was available. The near-infrared light source $\left(\lambda_{\max }=\right.$ $850 \mathrm{~nm}$ ) is believed to be invisible to Weddell seals and their prey (Lythgoe \& Dartnell 1970, Lavigne et al. 1977, Nelson 1981). The camera, connected to the main housing by a cable, was mounted on top of the seal's head to obtain close-up images of the seal's eyes and muzzle and the area in front of the animal. The main housing contained an $8 \mathrm{~mm}$ video tape recorder (VTR), rechargeable lithium ion batteries, and an on-board microcomputer that controlled the VTR and data acquisition from the transducers. The video system was activated by an external switch and recorded for $6 \mathrm{~h}$. A separate housing (17 cm long and $5.5 \mathrm{~cm}$ in diameter) for the gimbaled flux-gate compass was positioned behind the main housing and connected to it with a cable. Transducers for pressure, water speed, and compass bearing were sampled once every second, and the data were stored on a PCMCIA card. Sound was recorded on one audio channel of the VTR with a hydrophone, with a frequency response of $50 \mathrm{~Hz}$ to $16 \mathrm{kHz}$. Flipper stroke frequency (recorded at $16 \mathrm{~Hz}$ ) was determined from the lateral motion of a resin-encased accelerometer $(6 \times 3 \times 2 \mathrm{~cm})$ mounted near the base of the tail and connected to the main housing by a thin cable.

Weddell seals were captured with a purse-string net on the sea ice along the southwestern shore of Ross Island and transported to a research hut in a sled. Newly captured seals were sedated with an intramuscular injection of ketamine hydrochloride $\left(2 \mathrm{mg} \mathrm{kg}^{-1}\right.$, Fort Dodge Laboratories) and diazepam $\left(0.1 \mathrm{mg} \mathrm{kg}^{-1}\right.$, 
Steris), weighed, and placed in a climate-controlled research hut positioned over a $1.3 \mathrm{~m}$ diameter hole drilled through $3 \mathrm{~m}$ of sea ice. After cleaning the fur in the mid-dorsal area of the seal with acetone, a sheet of neoprene rubber $(0.5 \mathrm{~cm}$ thick and $50 \mathrm{~cm}$ in diameter) was glued to the fur along the dorsal midline above the shoulders with neoprene rubber cement. The main housing rested in a molded, non-compressible foam cradle that was attached to the neoprene rubber. A small piece of neoprene rubber was glued to the top of the seal's head for mounting the camera. The compass housing and accelerometer were glued to the fur in a similar fashion. Once mounted on the animal, the video system and data recorder were neutrally buoyant.

Seals were allowed $18 \mathrm{~h}$ to recover from sedation before being released through a trap door into the ice hole beneath the hut. The hole was located sufficiently far from other cracks so that the animals could not escape. The water beneath the hut was $585 \mathrm{~m}$ deep. Instrumented seals began performing dives similar to those of free-ranging seals within $24 \mathrm{~h}$ of release. The main housing of the video system was removed from the seal every 6 to $12 \mathrm{~h}$, while the animal rested in the ice hole, to download the data and replace the batteries and videotape, before reattaching the housing to the seal. Each instrumented seal was studied for 4 to 5 $d$, after which it was allowed to haul out onto the ice through a second hole and returned to the site of capture. All procedures were in accordance with animal use protocols of Texas A\&M University.

Each $8 \mathrm{~mm}$ videotape was duplicated in VHS format immediately after recovery. During duplication, a realtime clock code was superimposed on the video display from a signal encoded on the audio track. Videotapes were screened for encounters with prey, almost entirely fishes (Fuiman et al. 2002). Encounters are defined as prey that were pursued or captured. Because of the low light conditions under the ice, most prey were visible only $1 \mathrm{~m}$ or less from the camera mounted on the seal's head and overlooking the muzzle (Fig. 1). As a result, small prey were only seen during close pursuit and capture or, in the case of large Dissostichus, close inspection. Silverfish were identified by their small size (ca. 1.5 to 2.0 times the width of the seal's muzzle), pointed snout, compressed body, brightly reflective surface, and lack of dark pigmentation. Seals pursued the small sub-ice fish Pagothenia borchgrevinki on 5 occasions, but we could not be certain that they captured the fish. Pagothenia were recognized by their larger size, blunt head, and darker pigmentation. The large size of toothfish (ca. 1 to $2 \mathrm{~m}$ long) made their identification unmistakable during pursuit or capture.

We generated 3D dive paths for 758 dives made by the 10 adult seals and computed 58 descriptors for each dive path (Appendix 1). We used these descriptors to

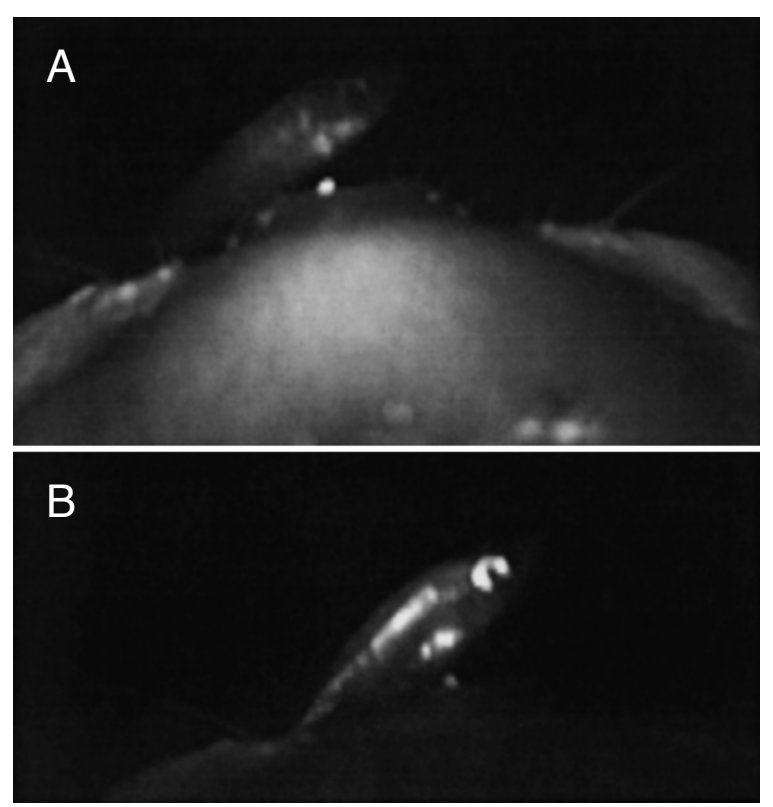

Fig. 1. Leptonychotes weddellii preying upon Pleuragramma antarcticum. Images from the video and data recorder. (A) Looking over the seal's head as it pursues a silverfish.

(B) Seal captures and swallows the silverfish

classify dives into groups, using a statistical approach similar to that of Schreer \& Testa $(1995,1996)$. Nonhierarchical clustering (also known as $k$-means clustering) was applied using the FASTCLUS procedure of SAS statistical software (Version 8.2). This type of clustering partitions a set of objects into a selected number of groups by maximizing between-cluster variation and minimizing within-cluster variation. It does not resolve relationships within each cluster and, as such, is simpler and less restrictive than hierarchical clustering procedures. The 58 dive descriptors were standardized (to a mean of 0 and an SD of 1.0) before applying the clustering procedure. Non-hierarchical clustering requires designation of the resulting number of groups (clusters) to define a priori. We conducted 9 cluster analyses of the data, specifying 2 to 10 clusters. The final classification was selected from among the 9 analyses by examining the pseudo $F$-statistic, observed overall $\mathrm{R}^{2}$, and cubic clustering criterion reported by the FASTCLUS procedure, acknowledging the tendency of the latter criterion to discover more clusters in a dataset than really exist (Milligan \& Cooper 1985, Schreer \& Testa 1996), as well as the size of the resulting clusters and the jackknifed classification results from subsequent discriminant analyses. Discriminant analysis was also used to test whether the clusters were significantly different and to identify the variables that contributed most strongly to the separation of classes of dives (clusters) defined by the cluster analysis. Variables were considered important to dis- 
crimination if the absolute value of the standardized coefficient was large relative to the remaining coefficients (scree plot analysis). Discriminant analyses were performed on raw data values using a forward stepwise procedure and a criterion of $p=0.15$ to add or remove variables from the analysis (Systat 10.2).

\section{RESULTS}

\section{Multivariate classification of dives}

Nine cluster analyses were performed to generate dive classifications that consisted of 2 to 10 clusters. The 3 statistics used to guide selection of the final number of clusters - pseudo $F$, overall $\mathrm{R}^{2}$, and cubic clustering criterion - suggested that our data set could be resolved into at least 6 clusters, and perhaps as many as 9. Each of these classifications, however, contained 3 or 4 trivial clusters of 1 or 2 members (dives), so that the number of meaningful clusters ranged from 3 to 5 . We selected the 8-cluster classification, which had 4 meaningful clusters, as a compromise. After eliminating 5 of the 758 dives that were assigned to trivial clusters, we computed a discriminant analysis for 4 clusters. Jackknifed discriminant classification success for this classification was $95 \%$ overall, with classification success ranging from 92 to $99 \%$ for individual classes of dives. Thus, this classification combined good resolution of diving behaviors (4 classes) with a high level of confidence (>92\%). Increasing the number of clusters to 5 resulted in lower classification success $(87 \%)$ for at least 1 cluster.

Discriminant analysis showed that the 4 clusters (dive types) were significantly distinct (Pillai's trace $=$ 2.26, $F_{78,2178}=85.6, \mathrm{p}<0.001$ for overall differences; $F_{26,724}>71.0, \mathrm{p}<0.001$ for all pairs of clusters). They were distinguished using 26 of the variables, representing attributes of position, time, distance, speed, angle, and linearity of the dive path (Table 1). The analysis also revealed that the 102 Type 1 dives were especially distinctive (Fig. 2a). All but 3 Type 1 dives $(97 \%)$ were correctly classified by the jackknife crossvalidation procedure; the 3 errors were assigned to Type 2. Standardized canonical coefficients (Table 2) showed that the first discriminant axis separated the 4 dive types on the basis of differences in swimming path linearity (INXY_NGDR, INXYZ_NGDR, OUTXYZ_NGDR, OUTXY_NGDR [variable names are defined in Appendix 1]) and distance traveled (INDIST_TOT, FARPNT_DIST). Dive Types 1 and 2 occupied extreme positions along this axis (Fig. 2). Jackknife cross-validation showed $92 \%$ correct classification of Type 2 dives; all misclassifications were assigned to Type 3.
Table 1. Classification functions for discriminating 4 dive types. A dive is assigned to one of 4 dive types by multiplying the value of each variable by the corresponding coefficient and summing these products plus the constant. This is repeated for each column of coefficients. The dive is assigned to the dive class with the largest sum. See Appendix 1 for a description of each variable

\begin{tabular}{|lrrrr|}
\hline \multirow{2}{*}{ Variable } & \multicolumn{5}{c}{ Dive type } \\
\cline { 2 - 5 } & \multicolumn{1}{c}{1} & \multicolumn{1}{l}{2} & \multicolumn{1}{c|}{3} \\
\hline Constant & -675.75 & -636.09 & -662.25 & -667.40 \\
FARPNT_X & 0.0019 & 0.0050 & 0.0050 & 0.0055 \\
FARPNT_Y & 0.0001 & 0.0023 & 0.0024 & 0.0027 \\
DEP_CV & 44.671 & 46.673 & 41.253 & 40.008 \\
FARPNT_DEPTH & 0.153 & 0.035 & 0.043 & 0.030 \\
INDEP_CV & -25.537 & -24.564 & -21.374 & -18.402 \\
CLOCK_FARPT & 21.215 & 18.470 & 19.911 & 19.144 \\
TIME_FARPT & 11687.1 & 11112.8 & 13080.7 & 19185.1 \\
DURA_160 & -1.645 & -0.822 & -0.961 & -0.279 \\
DURA & -5.324 & -5.182 & -4.876 & -7.954 \\
INDURA_160 & 0.889 & -2.390 & -2.410 & -4.247 \\
INDURA & -0.798 & 0.028 & 0.162 & 0.321 \\
FARPNT_DIST & -0.278 & -0.228 & -0.237 & -0.222 \\
INDIST_TOT & 0.165 & 0.128 & 0.128 & 0.158 \\
OUTDIST_TOT & 0.098 & 0.086 & 0.077 & 0.065 \\
INSPEED_MX & 16.005 & 18.716 & 18.058 & 17.005 \\
OUTSPEED_MN & 158.22 & 144.44 & 151.88 & 160.21 \\
SPEED_MN & -189.66 & -189.84 & -182.80 & -192.46 \\
INBRNG_R & 5.734 & 0.101 & 3.642 & -1.026 \\
OUTVANG1_CV & 0.058 & 0.115 & 0.080 & 0.089 \\
INXY_NGDR & -857.22 & -779.26 & -790.16 & -791.51 \\
INXYZ_NGDR & 849.29 & 782.91 & 798.19 & 802.49 \\
INZ_NGDR & 470.11 & 525.87 & 518.73 & 523.82 \\
OUTXY_NGDR & 266.07 & 202.78 & 216.30 & 210.44 \\
OUTXYZ_NGDR & -266.04 & -188.37 & -191.66 & -181.31 \\
OUTZ_NGDR & 747.23 & 709.30 & 702.83 & 690.82 \\
XY_NGDR & 156.80 & 118.07 & 125.86 & 120.52 \\
& & & & \\
\hline
\end{tabular}

Standardized canonical coefficients showed that the second discriminant axis separated dive types according to dive duration (DURA), distance traveled (OUTDIST_TOT, FARPNT_DIST), and, secondarily, path linearity (OUTXYZ_NGDR) (Table 2). Dive Types 1 and 4 were at the extremes of this axis (Fig. 2). Seven of 108 Type 4 dives were incorrectly classified by jackknife cross-validation; 6 of these were classified as Type 3 and 1 as Type 1.

Total duration (DURA), inbound total distance (INDIST_TOT), and mean swimming speed (SPEED_MN) were the most important variables on the third discriminant axis, which distinguished Type 3 dives from the other types (Table 2, Fig. 2). Jackknife cross-validation success was highest for Type 3 dives $(99 \%)$; misclassifications (4 of 271 dives) were equally distributed between Type 1 and Type 2 dives.

As expected, the data set contained some redundancy. There were significant correlations even among the 10 variables that contributed most strongly (largest standardized canonical coefficients) to the 3 discriminant axes (variables in bold in Table 2). For example, correlation coefficients for the 3 measures of dive dis- 

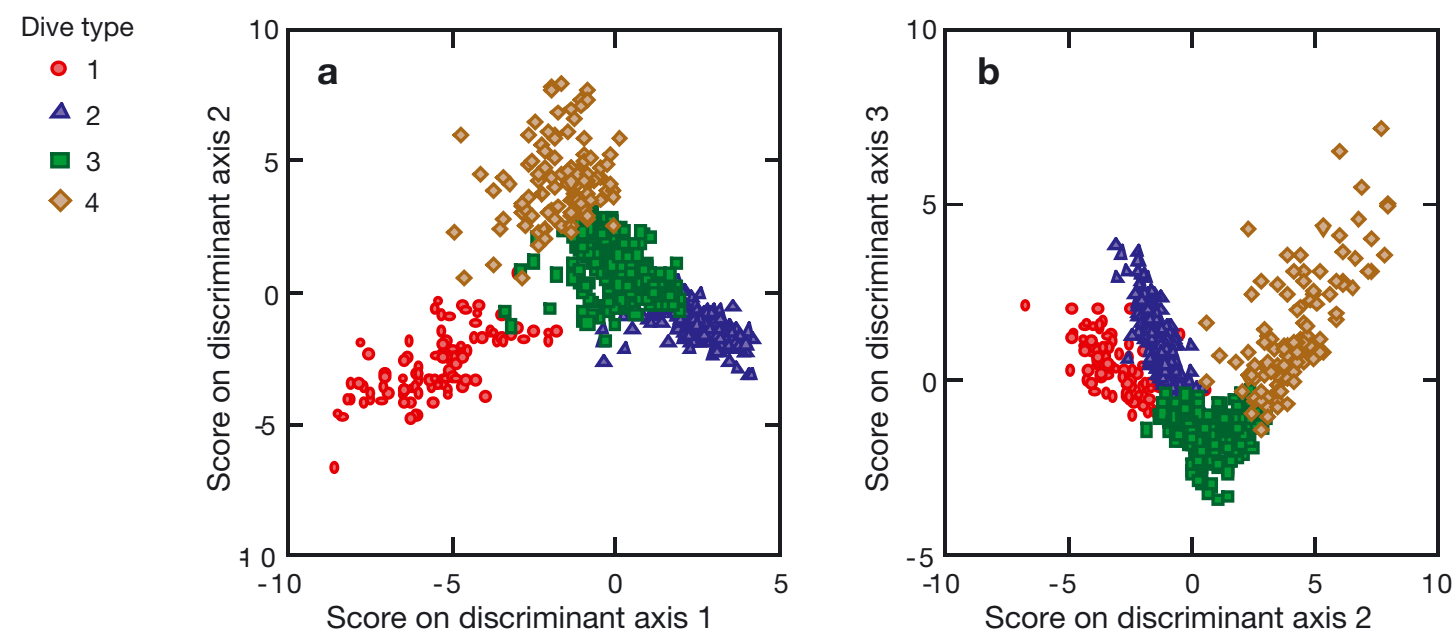

Fig. 2. Results of discriminant analysis of 4 clusters derived from $k$-means cluster analysis. $(a, b)$ Two views of the discriminant function scores. Points represent individual dives, symbols identify clusters. (c, d) Two views of the standardized canonical coefficients for discriminant analysis. Minor coefficients were omitted for clarity
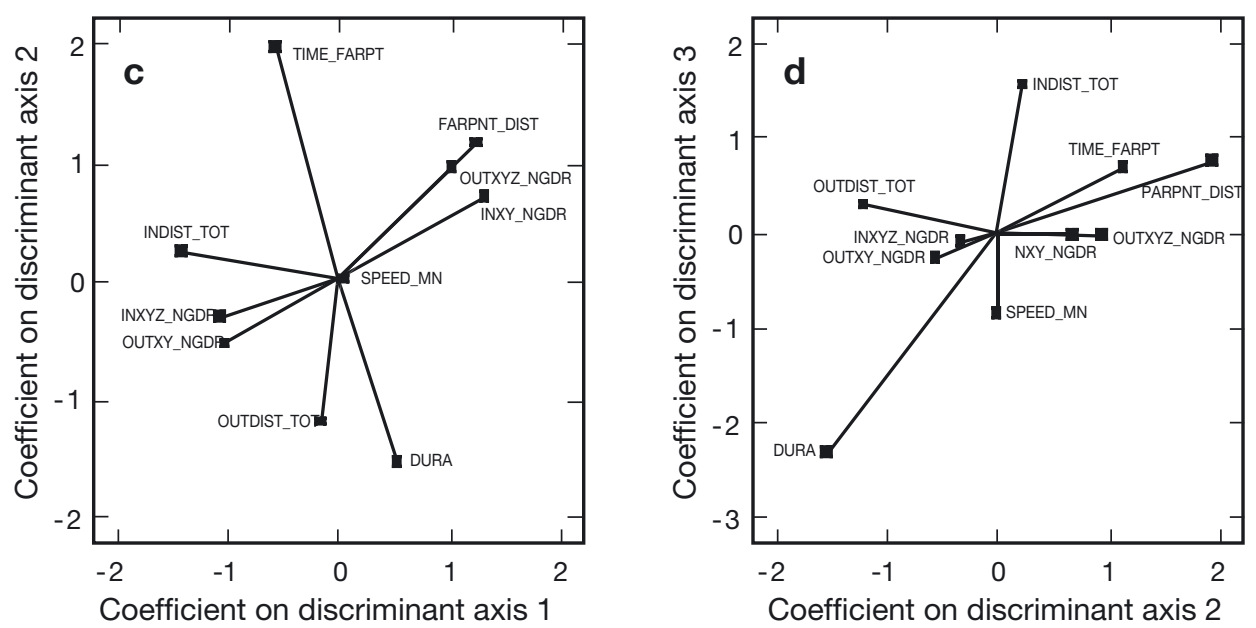

tance (Table 2) exceeded 0.97 and the correlation between the 2 dive duration variables was 0.99 . The 2 measures of dive path linearity on the outbound leg of a dive were highly correlated with each other, as were measures of linearity for the inbound leg $(\mathrm{r}>0.96)$. However, linearity measures for the outbound leg were not highly correlated with linearity measures for the inbound leg ( $\mathrm{r}=0.44$ to 0.55 ). Relationships among different classes of dive attributes shown in Table 2 were generally weaker. The 3 measures of dive distance were highly correlated with the 2 measures of dive duration ( $\mathrm{r}=0.94$ to 0.97 ). Mean swimming speed was moderately correlated with distances and durations ( $\mathrm{r}=0.61$ to 0.72 ). All other relationships between the important (bold) variables in Table 2 had correlation coefficients less than 0.58 .

\section{Classification with fewer variables}

Given this redundancy in the information contained in the most important variables from the discriminant analysis, we examined individual variables to see whether an acceptable level of discrimination could be achieved with a smaller set of variables. We also explored the efficacy of identifying the 4 classes of dives with variables that can be obtained from TDRs deployed with speed sensors.

The 4 dive types could be distinguished with 3 simple hierarchical decision rules based on 3 variables. The best discrimination using this approach was achieved with mean depth, far-point distance (the net 3D distance between the start of a dive and the far point), and mean speed. The decision tree shown in Fig. 3a yielded an overall classification success of $91 \%$. Assignments of dive Types 1, 2, 3, and 4 were 92, 88, 91, and $96 \%$ correct, respectively, as compared to 97 , 92,99 , and $94 \%$ for the same dive types using the discriminant analysis.

Of the 3 variables employed in this decision tree, mean depth can be measured by a TDR and mean speed can be measured with a speed sensor. However, far-point distance requires 3D tracking. Nevertheless, nearly as good discrimination of the 4 dive types could 
Table 2. Canonical discriminant functions, standardized by within variances, sorted by their importance to discriminating dive types. Variables and coefficients in bold are those that had the strongest effect on discrimination

\begin{tabular}{|lrrr|}
\hline Variable & \multicolumn{3}{c}{ Discriminant axis } \\
\cline { 2 - 4 } & \multicolumn{1}{c}{1} & 2 & \multicolumn{1}{c}{3} \\
\hline INDIST_TOT & $\mathbf{- 1 . 4 1 0}$ & 0.236 & $\mathbf{1 . 5 5 0}$ \\
INXY_NGDR & $\mathbf{1 . 3 2 1}$ & 0.687 & -0.029 \\
FARPNT_DIST & $\mathbf{1 . 2 4 2}$ & $\mathbf{1 . 1 4 4}$ & 0.676 \\
INXYZ_NGDR & $\mathbf{- 1 . 0 5 8}$ & -0.318 & -0.112 \\
OUTXYZ_NGDR & $\mathbf{1 . 0 2 0}$ & $\mathbf{0 . 9 4 7}$ & -0.038 \\
OUTXY_NGDR & $\mathbf{- 1 . 0 1 8}$ & -0.547 & -0.288 \\
TIME_FARPT & -0.564 & $\mathbf{1 . 9 4 8}$ & 0.738 \\
DURA & 0.532 & $\mathbf{- 1 . 5 3 7}$ & $-\mathbf{2 . 3 3 5}$ \\
OUTDIST_TOT & -0.160 & $\mathbf{- 1 . 2 0 1}$ & 0.285 \\
SPEED_MN & 0.044 & 0.002 & $-\mathbf{0 . 8 6 5}$ \\
INBRNG_R & -0.091 & -0.078 & -0.229 \\
DURA_160 & 0.144 & 0.291 & 0.222 \\
XY_NGDR & -0.531 & -0.333 & -0.171 \\
DEP_CV & 0.061 & -0.157 & 0.163 \\
INDURA_160 & -0.285 & -0.532 & -0.151 \\
CLOCK_FARPT & -0.081 & -0.019 & -0.096 \\
OUTVANG1_CV & 0.076 & -0.004 & 0.087 \\
INDURA & 0.187 & 0.276 & -0.085 \\
INDEP_CV & -0.016 & 0.218 & -0.073 \\
OUTZ_NGDR & -0.140 & -0.244 & 0.043 \\
INSPEED_MX & 0.154 & -0.013 & -0.038 \\
OUTSPEED_MN & -0.591 & 0.397 & -0.033 \\
INZ_NGDR & 0.245 & 0.170 & 0.024 \\
FARPNT_Y & 0.114 & 0.125 & -0.022 \\
FARPNT_DEPTH & -0.730 & -0.613 & 0.015 \\
FARPNT_X & 0.141 & 0.147 & 0.0003 \\
& & & \\
\hline
\end{tabular}

be achieved with a TDR and speed sensor by replacing far-point distance with total distance traveled (total distance traveled $=$ sum of speeds). The decision tree in Fig. $3 \mathrm{~b}$ resulted in an overall classification success of $92,88,90$, and $96 \%$ correct classification for Type 1, 2 , 3 , and 4 dives, respectively. That is, classification of only Type 3 dives was reduced by changing variables, but only slightly.

\section{Characterization and ecological role of dive types}

$$
\text { Type } 1 \text { dives }
$$

These dives were intermediate in duration but much deeper than the other 3 types (Table 3, Fig. 4). In addition, Type 1 dives had the steepest outbound (descent) and inbound (ascent) angles. Average swimming speed was similar to Type 4 dives, but the highest burst swimming speed $\left(5.1 \mathrm{~m} \mathrm{~s}^{-1}\right)$ recorded during this study occurred during a Type 1 dive while the seal pursued a toothfish at depth. The far-point distance and total distance traveled by the seals were 46 to $59 \%$ of the values for Type 4 dives, but greater than Type 2 and 3 dives. In addition, the swimming path was not as linear (based on the NGDR) as Type 4 dives, but similar to Type 3 dives. The average dive duration was within the estimated aerobic dive limit (ADL) of 23 min (Kooyman et al. 1980, Davis \& Kanatous 1999), but a few dives $(7 \%)$ exceeded it. Type 1 dives represented $14 \%$ of the 753 dives for which we had both video observations and data, but $29 \%$ of the total time (121.8 h) that the seals were submerged. Although they were not the most common dive type, they accounted for a significant proportion of the total time spent submerged because of their long duration, which was exceeded only by Type 4 dives.

Analysis of the video recordings that accompanied the dive data allowed us to attribute an ecological role based on behavior. We considered any dive in which a fish (silverfish, toothfish, or Pagothenia borchgrevinki) was pursued or captured on the video recording as a foraging dive. We also noted when the sea floor and benthic invertebrate community were seen (bottom dives) and when seals came in contact with the underice surface. A total of 311 silverfish encounters were observed in 55 dives. Of these, 51 dives with 304 encounters (93\%) were Type 1 and 4 dives with 7 encounters were Type 3 . Of the 10 dives with toothfish encounters, 7 were Type 1 and 3 were Type 3 . Thus, $89 \%$ of dives in which silverfish or toothfish appeared were Type 1 dives. There were equal numbers (51 each) of Type 1 dives in which silverfish were observed and not observed. This indicates that the 102 dives in Type 1 did not cluster together merely because the seals encountered a fish. Therefore, we will refer to all Type 1 dives as foraging dives, whether or not a fish was actually encountered.

Two seals swam to the bottom of McMurdo Sound 11 times. The average maximum depth of these deepest dives was $569 \pm 9.6 \mathrm{~m}$. All bottom encounters occurred in Type 1 dives. Although no fishes were encountered in any of these bottom dives, dive descriptors were consistent with those of foraging dives, and they were classified together with known foraging dives. There were no encounters with sub-ice Pagothenia during Type 1 dives. Encounters with the under-ice surface occurred only in Type 3 dives.

\section{Type 2 dives}

Type 2 dives were very short duration, shallow dives in which the seals departed and returned at shallow angles, swam at a slow speed, did not travel far from the hole, and swam a path that was the least linear of the 4 dive types (Table 3, Fig. 4). Maximum duration (12.6 $\mathrm{min}$ ) of these dives was well within the estimated 
a

Classification success

Type 1 92\%

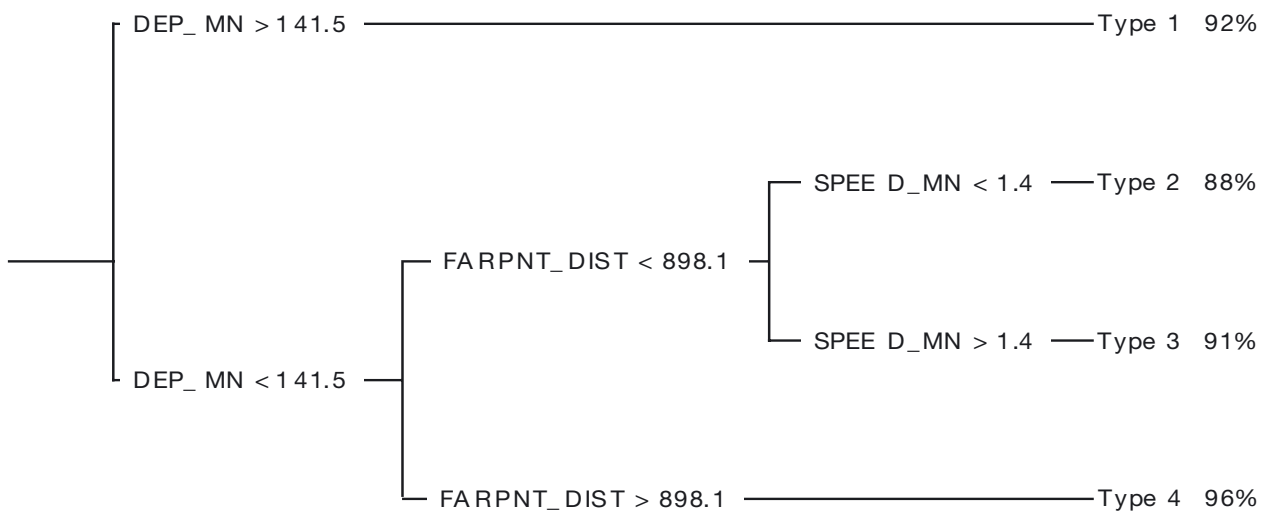

Fig. 3. Decision trees for classifying dives by Weddell seals Leptonychotes weddellii from an isolated hole using a small number of variables. (a) Best results using available variables. (b) Best results using variables that can be obtained from a time-depth recorder with a speed sensor. Classification success is the percentage of dives that were assigned to the dive type identified by the cluster analysis. Overall classification success for both decision trees is $91 \%$. See Appendix 1 for definitions

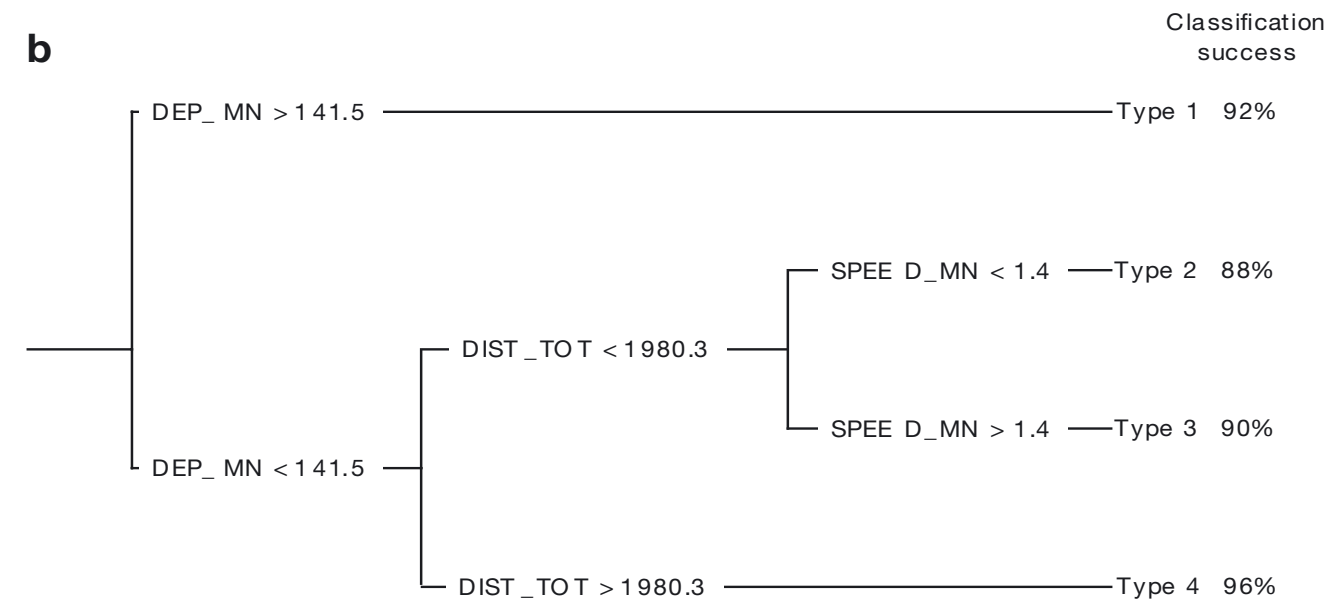

ADL of ca. 23 min. Fishes were never encountered during these dives. The seals never swam up to the underice surface (except on final ascent) or descended to the sea floor during Type 2 dives. Type 2 dives represented $36 \%$ of the 753 dives for which we had both video recordings and data, but only $7 \%$ of the time that the seals were submerged.

\section{Type 3 dives}

Compared to Type 2 dives, these were 2.2 times longer in duration and 2.6 times deeper, but much shorter and shallower than Type 1 and 4 dives (Table 3, Fig. 4). Outbound and inbound angles were nearly identical to Type 2 dives, but much less than Type 1 dives and greater than Type 4 dives. The seals swam 1.6 times faster than Type 2 dives, but slower (86 and $82 \%$, respectively) than Type 1 and 4 dives. Type 3 dives were more linear than Type 1 and 2 dives, but less linear than Type 4 dives. Compared to Type 2 dives, the far-point distance was 5 times further from the ice hole during Type 3 dives, but not as far (56 and $26 \%$, respectively) as Type 1 and 4 dives. The average total distance swum was 3.5 times further than Type 2 dives, but only 46 and $27 \%$, respectively, of that for Type 1 and 4 dives. The maximum duration (17.6 min) of these dives was well within the estimated ADL of ca. 23 min. Type 3 dives were numerically common $(36 \%)$, but they still represented a relatively small proportion (16\%) of the total time spent submerged. Silverfish were rarely encountered during these dives ( 7 encounters out of 311 ), although toothfish (3 encounters out of 10) and Pagothenia (5 total encounters during 2 dives) occurred during Type 3 dives. The seals sometimes swam up to the under-ice surface, but they never descended to the sea floor. 
Table 3. Summary statistics (mean $\pm \mathrm{SD}$ ) for 4 dive types. $\mathrm{N}$ is the number of dives of each type. Variables in bold had the strongest effect on discrimination (see Table 2)

\begin{tabular}{|c|c|c|c|c|}
\hline $\begin{array}{l}\text { Attribute } \\
\text { Variable }\end{array}$ & Type 1 & Type 2 & Type 3 & Type 4 \\
\hline \multicolumn{5}{|l|}{ Position } \\
\hline $\begin{array}{l}\text { Mean depth } \\
\left(\mathrm{DEP} \_M N\right)(\mathrm{m})\end{array}$ & $200 \pm 54$ & $16 \pm 17$ & $41 \pm 26$ & $65 \pm 32$ \\
\hline $\begin{array}{l}\text { Maximum depth } \\
\text { (DEP_MX) (m) }\end{array}$ & $378 \pm 93$ & $30 \pm 29$ & $81 \pm 52$ & $142 \pm 73$ \\
\hline $\begin{array}{l}\text { Far-point depth } \\
\text { (FARPNT_DEPTH) (m) }\end{array}$ & $347 \pm 103$ & $26 \pm 26$ & $68 \pm 47$ & $118 \pm 70$ \\
\hline \multicolumn{5}{|l|}{ Duration } \\
\hline $\begin{array}{l}\text { Total duration } \\
\text { (DURA) (min) }\end{array}$ & $15.0 \pm 4.2$ & $3.6 \pm 2.6$ & $7.9 \pm 3.9$ & $24.7 \pm 7.76$ \\
\hline $\begin{array}{l}\text { Outbound duration } \\
\text { (OUTDURA) (min) }\end{array}$ & $7.7 \pm 2.7$ & $2.1 \pm 1.5$ & $4.3 \pm 2.2$ & $13.3 \pm 3.86$ \\
\hline $\begin{array}{l}\text { Inbound duration } \\
\text { (INDURA) (min) }\end{array}$ & $7.2 \pm 2.3$ & $1.5 \pm 1.4$ & $3.5 \pm 1.8$ & $10.8 \pm 4.18$ \\
\hline \multicolumn{5}{|l|}{ Distance } \\
\hline $\begin{array}{l}\text { Total distance } \\
(\mathrm{DIST} \text { TOT) (m) }\end{array}$ & $1891 \pm 447$ & $252 \pm 213$ & $877 \pm 502$ & $3207 \pm 983$ \\
\hline $\begin{array}{l}\text { Outbound distance } \\
\text { (OUTDIST_TOT(m) }\end{array}$ & $922 \pm 270$ & $129 \pm 107$ & $445 \pm 261$ & $1619 \pm 483$ \\
\hline $\begin{array}{l}\text { Inbound distance } \\
\text { (INDIST_TOT) (m) }\end{array}$ & $970 \pm 254$ & $123 \pm 121$ & $433 \pm 246$ & $1574 \pm 485$ \\
\hline $\begin{array}{l}\text { Far-point distance } \\
\text { (FARPNT_DIST) (m) }\end{array}$ & $671 \pm 243$ & $75 \pm 63$ & $375 \pm 228$ & $1465 \pm 455$ \\
\hline \multicolumn{5}{|l|}{ Speed } \\
\hline $\begin{array}{l}\text { Mean speed } \\
\text { (SPEED_MN) }\left(\mathrm{m} \mathrm{s}^{-1}\right)\end{array}$ & $2.1 \pm 0.2$ & $1.1 \pm 0.3$ & $1.8 \pm 0.3$ & $2.2 \pm 0.3$ \\
\hline $\begin{array}{l}\text { Maximum speed } \\
\left(\text { SPEED_MX) }\left(\mathrm{m} \mathrm{s}^{-1}\right)\right.\end{array}$ & $3.2 \pm 0.4$ & $2.2 \pm 0.5$ & $2.8 \pm 0.4$ & $3.1 \pm 0.3$ \\
\hline \multicolumn{5}{|l|}{ Angle } \\
\hline $\begin{array}{l}\text { Outbound vertical angle } \\
\text { (OUTVANG_MN) } \\
\text { (degrees) }\end{array}$ & $-24 \pm 6$ & $-13 \pm 6$ & $-11 \pm 6$ & $-5 \pm 3$ \\
\hline $\begin{array}{l}\text { Inbound vertical angle } \\
\text { (INVANG_MN) (degrees) }\end{array}$ & $22 \pm 7$ & $13 \pm 8$ & $10 \pm 7$ & $5 \pm 3$ \\
\hline \multicolumn{5}{|l|}{ Linearity } \\
\hline $\begin{array}{l}\text { Path linearity } \\
\text { (XYZ_NGDR) }\end{array}$ & $0.70 \pm 0.12$ & $0.60 \pm 0.13$ & $0.84 \pm 0.07$ & $0.91 \pm 0.04$ \\
\hline $\begin{array}{l}\text { Horizontal path linearity } \\
\text { (XY_NGDR) }\end{array}$ & $0.65 \pm 0.19$ & $0.61 \pm 0.15$ & $0.86 \pm 0.08$ & $0.93 \pm 0.03$ \\
\hline $\begin{array}{l}\text { Outbound path linearity } \\
\text { (OUTXYZ_NGDR) }\end{array}$ & $0.73 \pm 0.14$ & $0.59 \pm 0.16$ & $0.84 \pm 0.08$ & $0.90 \pm 0.05$ \\
\hline $\begin{array}{l}\text { Outbound horizontal } \\
\text { path linearity } \\
\text { (OUTXY_NGDR) }\end{array}$ & $0.68 \pm 0.20$ & $0.61 \pm 0.18$ & $0.86 \pm 0.09$ & $0.92 \pm 0.05$ \\
\hline $\begin{array}{l}\text { Inbound path linearity } \\
\text { (INXYZ_NGDR) }\end{array}$ & $0.70 \pm 0.16$ & $0.66 \pm 0.18$ & $0.86 \pm 0.09$ & $0.93 \pm 0.03$ \\
\hline $\begin{array}{l}\text { Inbound horizontal } \\
\text { path linearity } \\
\text { (INXY_NGDR) }\end{array}$ & $0.65 \pm 0.21$ & $0.67 \pm 0.19$ & $0.88 \pm 0.09$ & $0.95 \pm 0.03$ \\
\hline $\mathrm{N}$ & 102 & 272 & 271 & 108 \\
\hline
\end{tabular}

Type 4 dives

Type 4 dives were the longest in duration but still relatively shallow compared to Type 1 dives (Table 3, Fig. 4). In addition, they had the lowest average outbound and inbound angles of the 4 dive types. Average swimming speed was similar to Type 1 dives. In Type 4 dives, seals ranged the furthest distance from the ice hole (far-point distance up to $2805 \mathrm{~m}$ ) and traveled the longest total distance (up to $6012 \mathrm{~m})$. Type 4 dives were the most linear, especially in the horizontal plane where the seals followed a nearly linear path to and from the hole. Of these dives, $21 \%$ exceeded the estimated ADL of $23 \mathrm{~min}$, with the longest dive recorded being $57.0 \mathrm{~min}$. Numerically, Type 4 dives were not very common $(14 \%)$, but they accounted for the greatest proportion $(48 \%)$ of the total time spent submerged because of their long duration. As with Type 2 dives, fishes were never encountered, and the seals never approached the underice surface (except on final ascent) or sea floor.

\section{DISCUSSION}

This is the first study to classify marine mammal dives based on spatial and temporal variables derived from 3D movements and assign functions to the dive classifications based on video-recorded behavior. We believe this approach will greatly improve our understanding of the behavioral significance of different dive types. However, the seals in this study were constrained to dive from an isolated breathing hole in ice that was $3 \mathrm{~m}$ thick. Although free-ranging Weddell seals occur under similar circumstances, they are able to find other holes and interact with other seals. As a result, our data probably represent a subset of the spectrum of dive types used by free-ranging seals. For example, socializing and fighting, which are common when seals compete for breathing holes (R. W. Davis unpubl. 
Type 1

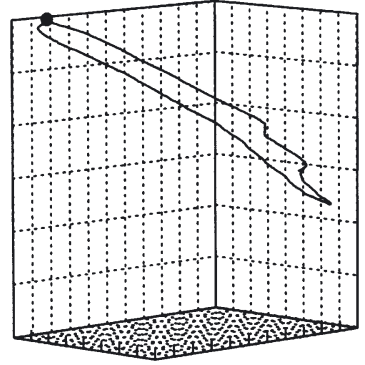

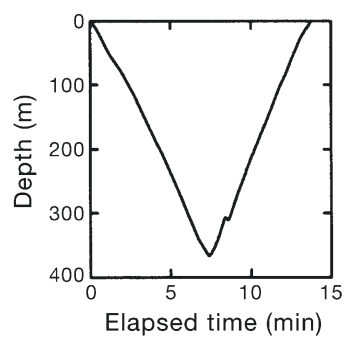

Type 2

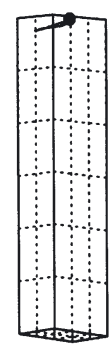

Type 3
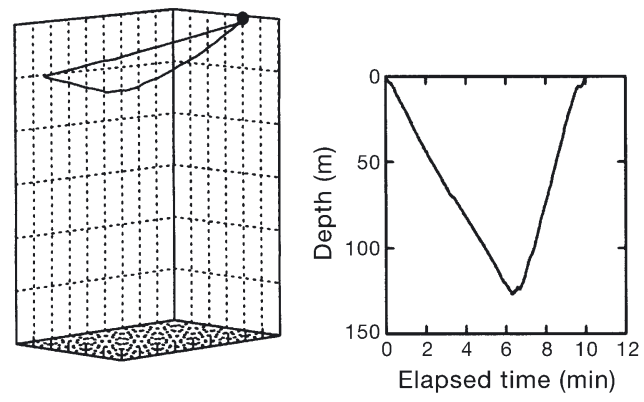

Type 4

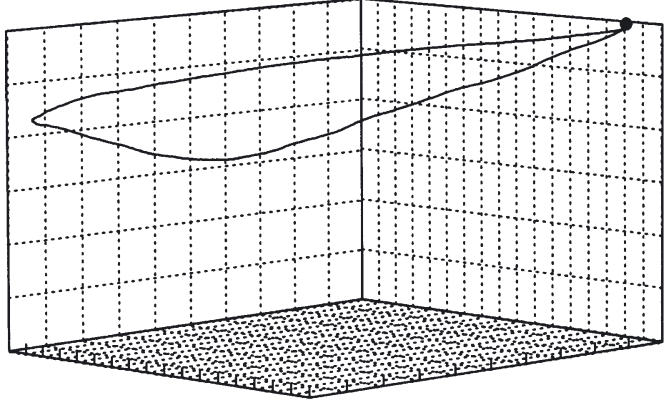

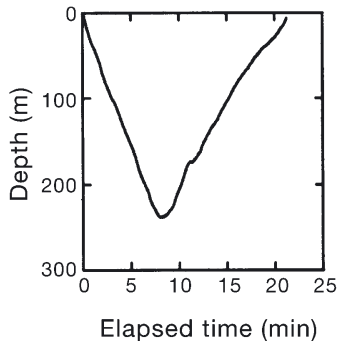

Fig. 4. Representative dives of each type of Leptonychotes weddellii dive shown as a 3D map and a time-depth profile. Dives were selected from near the centroid of each cluster (Fig. 1). Three-dimensional maps are scaled equally (increments of $50 \mathrm{~m}$ in the horizontal plane and $100 \mathrm{~m}$ on the vertical [depth] axis). Time-depth profiles are scaled independently of each other

obs.), did not occur, and vocalizations were rare. Nine of our seals were adult males, and some of them may have displayed territorial behavior (e.g. patrolling the area for other seals), especially in late November and early December when breeding occurs. Territorial behavior includes fights with other males and courtship of females. However, in the absence of other animals, none of these behaviors occurred in our study. In addition, our seals were constrained to one breathing hole because no other holes were present within a $3 \mathrm{~km}$ radius. This may have motivated some animals to make very long dives (e.g. 5 seals made dives $>40 \mathrm{~min}$ in duration) in an attempt to find other holes. These very long dives, which are rare in free-ranging Weddell seals (Kooyman et al. 1980, Castellini et al. 1992, Harcourt et al. 2000, Plotz et al. 2001, Hindell et al. 2002), occasionally take animals to the physiological limits of their breath-holding ability. As a result, the classification of dives in this study does not necessarily represent dives performed by free-ranging Weddell seals, but is a first step in classifying dives for which behavior and 3D movements have been recorded.
Type 1 (foraging) dives were similar to Pattern III dives described by Kooyman (1968) (Table 4, Fig. 5). However, $59 \%$ of Type 1 dives did not fall within the criteria for Pattern III dives (300 to $400 \mathrm{~m}$ deep and 8 to 15 min duration). Our Type 1 dives included deeper and shallower dives and dives of longer duration (only 2 dives were less than 8 min duration). By expanding the criteria for Pattern III dives to depths of 200 to $585 \mathrm{~m}$ and to durations of 7 to $23 \mathrm{~min}$, only the longest duration Type 1 dives (9\%) which exceed the 23 min ADL would be excluded. Therefore, Type 1 dives are similar in mean maximum depth and duration to Pattern III dives, but the ranges for both criteria are broader. Our video observations confirmed that Type 1 dives were used for foraging, which was the function assumed for Pattern III dives by Kooyman (1968).

Type 2 dives were similar to Pattern I dives described by Kooyman (1968) (Table 4, Fig. 5). The seals' close proximity to the ice hole, slow movements and absence of encounters with fishes indicate that these were not hunting dives. Type 3 dives were 1.6 times longer in duration than Pattern I dives and, on the whole, do not fit into any dive pattern described by Kooyman (1968), 
Table 4. Leptonychotes weddellii. Comparison of dive classifications for Weddell seals

\begin{tabular}{|c|c|c|c|c|c|}
\hline \multirow{2}{*}{$\overline{\text { Dive type }}$} & \multirow{2}{*}{$\begin{array}{l}\text { Kooyman (1968) } \\
\text { Description and function }\end{array}$} & \multicolumn{2}{|c|}{ Schreer \& Testa (1995) } & \multirow{2}{*}{\multicolumn{2}{|c|}{$\begin{array}{ll} & \text { This study } \\
\text { Dive type } & \text { Description and function }\end{array}$}} \\
\hline & & Dive type & Description and function & & \\
\hline \multirow[t]{2}{*}{ Pattern I } & \multirow[t]{2}{*}{$\begin{array}{l}\text { Short-duration }(<5 \mathrm{~min}) \\
\text { and shallow }(<100 \mathrm{~m}) \text {. } \\
\text { Assumed to be associ- } \\
\text { ated with detection of } \\
\text { other seals, assessment } \\
\text { of under-ice conditions, } \\
\text { resting or fighting with } \\
\text { other seals }\end{array}$} & Category 1 & $\begin{array}{l}\text { Deep, square time-depth } \\
\text { profile with multiple small } \\
\text { ascents and descents } \\
\text { (wiggles) at the bottom. } \\
\text { Assumed to be foraging } \\
\text { dives }\end{array}$ & Type 1 & $\begin{array}{l}\text { Intermediate duration } \\
\text { (15 min), deep ( } 378 \mathrm{~m}) \text { dives } \\
\text { with steepest descent and } \\
\text { ascent angles. Swimming } \\
\text { path not as linear as Type } 4 \\
\text { dives. Known to be foraging } \\
\text { dives }\end{array}$ \\
\hline & & Category 2 & Deep, triangular time-depth & & \\
\hline \multirow[t]{2}{*}{ Pattern II } & $\begin{array}{l}\text { Long-duration }(>40 \\
\text { min) and relatively } \\
\text { shallow }(<200 \mathrm{~m}) .\end{array}$ & & $\begin{array}{l}\text { proflle. Assumed to be } \\
\text { associated with predator } \\
\text { avoidance and exploration }\end{array}$ & Iуре 2 & $\begin{array}{l}\text { very shallow }(30 \mathrm{~m}) \text { dives } \\
\text { with shallow descent and } \\
\text { ascent angles. Swimming }\end{array}$ \\
\hline & $\begin{array}{l}\text { Assumed to associated } \\
\text { with exploring the local } \\
\text { area for other breath- } \\
\text { ing holes }\end{array}$ & Category 3 & $\begin{array}{l}\text { Relatively shallow, skewed } \\
\text { right time-depth profile. } \\
\text { Assumed to result from the } \\
\text { seal following the sea floor } \\
\text { during ascent }\end{array}$ & & $\begin{array}{l}\text { path least linear of } 4 \text { dive } \\
\text { types. Assumed to be asso- } \\
\text { ciated with hole-guarding } \\
\text { or the detection of other } \\
\text { seals }\end{array}$ \\
\hline \multirow[t]{4}{*}{ Pattern III } & $\begin{array}{l}300 \text { to } 400 \mathrm{~m} \text { in depth, } \\
8 \text { to } 15 \mathrm{~min} \text { in duration, } \\
\text { with steep rates of } \\
\text { descent and ascent. } \\
\text { Assumed to be hunting } \\
\text { dives }\end{array}$ & Category 4 & $\begin{array}{l}\text { Relatively shallow, skewed } \\
\text { left time-depth profile. } \\
\text { Assumed to be associated } \\
\text { with resting or sleeping } \\
\text { underwater or following the } \\
\text { sea floor during descent }\end{array}$ & \multirow[t]{2}{*}{ Type 3} & $\begin{array}{l}\text { Short duration }(7.9 \mathrm{~min}), \\
\text { shallow }(81 \mathrm{~m}) \text { dives with } \\
\text { shallow descent and ascent } \\
\text { angles. Swimming path } \\
\text { more linear than Type } 1 \text { and } \\
2 \text { dives. Assumed to be } \\
\text { associated with exploring }\end{array}$ \\
\hline & & Category 5 & $\begin{array}{l}\text { Shallow rectangular time- } \\
\text { depth profile. Assumed to }\end{array}$ & & under-ice features \\
\hline & & & $\begin{array}{l}\text { be associated with explo- } \\
\text { ration or traveling }\end{array}$ & \multirow[t]{2}{*}{ Type 4} & \multirow{2}{*}{$\begin{array}{l}\text { Longest duration }(24.7 \mathrm{~min}) \\
\text { relatively shallow }(142 \mathrm{~m}) \\
\text { dives with shallowest } \\
\text { descent and ascent angles. } \\
\text { Swimming path most linear } \\
\text { of the } 4 \text { dive types. } \\
\text { Assumed to be associated } \\
\text { with exploring under-ice } \\
\text { features }\end{array}$} \\
\hline & & Category 6 & $\begin{array}{l}\text { Deep, square time-depth } \\
\text { profile without multiple, } \\
\text { small ascents and descents } \\
\text { (wiggles) at the bottom. } \\
\text { Assumed to be associated } \\
\text { with benthic foraging }\end{array}$ & & \\
\hline
\end{tabular}

although they appear to be intermediate between Pattern I and II dives (Table 4). Although we cannot rule out other functions, 3 encounters with shallowswimming toothfish and 5 encounters with sub-ice Pagothenia, all of which may have been opportunistic, indicate that successful prey capture may occasionally occur during Type 3 dives. However, their general characteristics are intermediate between Type 2 and 4 dives, which are not associated with feeding.

During an average Type 4 dive, the seal descended at a very shallow angle to a mean maximum depth of $142 \mathrm{~m}$, and tended to depart and return along a similar path so that the overall dive track was the most linear of the 4 dive types. These long-distance linear dives with no prey encounters are not hunting dives. In addition, they do not completely conform to Kooyman's (1968) Pattern II dives (Table 4), in which the total duration exceeds the ADL, possibly in an attempt to escape from the isolated experimenting hole. Although some of our Type 4 dives exceeded the ADL, most $(67 \%)$ were less than $40 \mathrm{~min}$ in duration and some $(11 \%)$ were deeper than $200 \mathrm{~m}$.

Types 2, 3 and 4 dives form a continuum from very short, low speed, non-linear dives that are close to the hole (Type 2), to progressively longer, higher speed, very linear dives that can range nearly $3 \mathrm{~km}$ from the hole (Type 4). Although the average depth becomes progressively deeper for these 3 dive types, respectively, overall they remain relatively shallow (mean maximum depth <142 m) compared to Type 1 foraging dives. There were no behaviors recorded on the video that allowed us to assign a function to Type 2, 3 and 4 dives as we did with Type 1 foraging dives. However, based on their 3D characteristics and absence of feeding, Type 2 dives may be associated with hole-guarding behavior or the detection of other seals. As the seals range progressively further from the ice hole (Type 3 and 4 dives), we hypothesize that they are exploring 
Fig. 5. Comparison of Weddell seal Leptonychotes weddellii dive classifications from Kooyman (1968), Schreer \& Testa (1995) and this study. Arrows indicate which of the dive types in this study correspond with Kooyman (1968) dive patterns and Schreer \& Testa (1995) dive categories. Dive types that do not correspond to any of the dive patterns or categories are indicated as unclassified. Percent correspondence is shown next to each arrow
Kooyman

(1968)

This study

Schreer \& Testa

(1995)

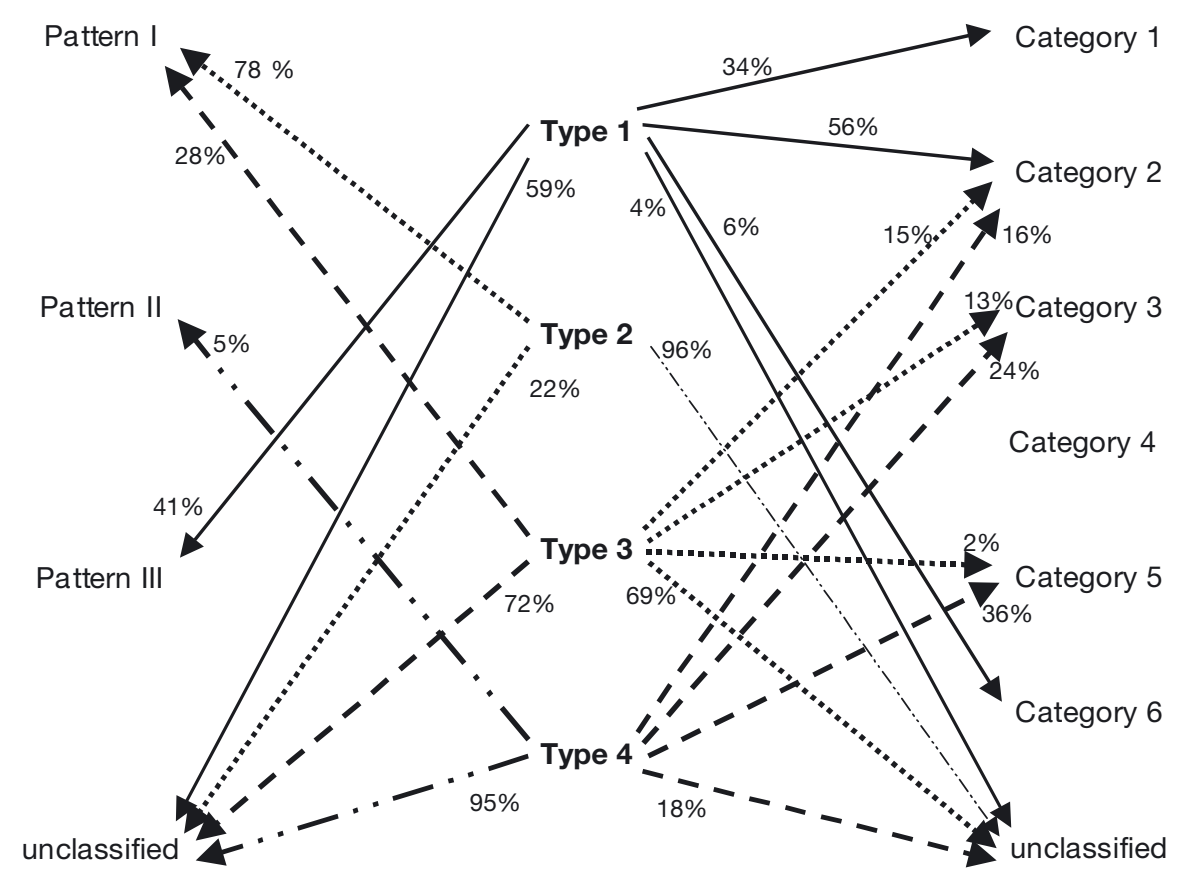

under-ice features (e.g. cracks and other holes). This behavior results in more linear dives that enable seals to relocate the isolated ice hole if they are unsuccessful in finding an alternative hole. Very long (e.g. 40 to $57 \mathrm{~min})$, 'anaerobic' dives, which we believe represent attempts by the seals to escape from the experimenting hole, have been observed infrequently in free-ranging Weddell seals (Kooyman et al. 1980), but may be important during migrations into ice-covered areas.

Schreer \& Testa $(1995,1996)$ classified Weddell seal dives manually and statistically into 6 categories using TDR data from free-ranging animals. They excluded dives less than $10 \mathrm{~min}$ in duration and less than $50 \mathrm{~m}$ deep from their analyses. A description of the timedepth profiles and suggested behavioral functions of these dives are shown in Table 4. We compared these dive categories to our 4 dive types. Of our Type 1 dives, $96 \%$ could be matched to one of these categories: 34 , 56 and $6 \%$ corresponded with Categories 1, 2 and 6, respectively (Fig. 5). Hence, video-recorded behavior supports the foraging function suggested by Schreer \& Testa $(1995,1996)$ for Categories 1 and 6, but we observed that Category 2 dives were also used for foraging.

Of our Type 2 dives, $96 \%$ failed to match any of Schreer \& Testa's $(1995,1996)$ categories because they were of the short duration or shallow depth excluded by those authors a priori (Fig. 5). In total, $69 \%$ of Type 3 dives also failed to match any of Schreer \& Testa's categories because they were too short in duration, too shallow, or had elements of more than one category. The remainder $(15,13$ and $2 \%)$ corresponded to Categories 2, 3 and 5, respectively (Fig. 5). Of our Type 4 dives, $18 \%$ did not match any of the categories, and most of the remaining dives $(16,24$ and $36 \%$ ) corresponded with Categories 2, 3, 5, respectively (Fig. 5).

Except for Category 4 dives, for which we only found 3 examples in our study, the other 5 categories of Schreer \& Testa (1995) correspond primarily to our Type 1 (Categories 1, 2 and 6), and Type 3 and 4 (Categories 2, 3 and 5) dives and may represent variations in one basic time-depth dive profile, Category 2 (i.e. the $\mathrm{V}$-shaped dive). This was the only time-depth dive profile that did not fit exclusively into one behavioral category. Our ability to divide 5 of the 6 dive categories identified by Schreer \& Testa (1995) into 2 functional types (i.e. foraging or exploration) is based on many variables that can only be derived from $3 \mathrm{D}$ dive profiles (i.e. far-point distance and several indices of the linearity of the dive) and simultaneous video-recorded behavior. Although some of the functions assumed by Schreer \& Testa (1995) were correct, others were not. For example, Category 2 dives were assumed to be associated with predator avoidance and exploration, but this time-depth profile corresponded with $56 \%$ of our Type 1 feeding dives. In addition, Category 3 dives were assumed to result from the seal following the sea floor during ascent, but this profile only corresponded 
with Type 3 and 4 dives, during which the seal never descended to the sea floor. This emphasizes the need for behavioral data in the interpretation of dive profiles and time-depth statistics.

The traditional tool for studying the diving behavior of Weddell seals and other pinnipeds is a TDR and, more recently, SLTDRs. These have produced thousands of dives recorded from many species. Their small size, low cost and ease of use will undoubtedly result in their continued use. It is therefore important to determine whether data from TDRs could be used to identify Type 1, 2, 3 and 4 dives. A decision tree based on average depth, speed and total distance traveled resulted in very good (ca. 91\%) classification of these 4 dive types. The first 2 variables are available from TDRs, and the third variable can be obtained by adding a speed (or distance) sensor. Hence, it may be possible to use TDR and speed data to study foraging and other types of behavior once the behavioral functions of dives have been determined. However, it is likely that many characteristics of different ecological dive types will vary by species, age class, and possibly gender, geographical region, or season. Therefore, it will be necessary to conduct studies such as ours that simultaneously evaluate underwater behavior and dive performance under certain conditions. Once those studies have been compiled, we may be able to discover common features of diving behavior that transcend age, gender, regional, seasonal, and perhaps even species differences, and allow us to determine the ecological roles of dives from a few simple parameters.

Acknowledgements. This research was supported by grants from the National Science Foundation, Office of Polar Programs (OPP-9614857, OPP-9708151, OPP-9618384) and the West Coast Office of the National Undersea Research Program (UAF98-0040). We thank the U.S. Antarctic Program for their logistical support and members of our field team, especially S. Kanatous, S. Kohin, R. Skrovan and L. Collier. Special thanks to S. Collier for assistance in the development of video and data recorder and to $\mathrm{M}$. Davis for analysis of the video tapes. We thank G. Davis for assistance in data analysis and P. Canton for assistance in manuscript preparation.

\section{LITERATURE CITED}

Andrew RD (1998) Remotely releasable instruments for monitoring the foraging behaviour of pinnipeds. Mar Ecol Prog Ser 175:289-294

Asaga T, Naito Y, Le Boeuf BJ, Sakurai H (1994) Functional analysis of dive types of female northern elephant seals. In: Le Boeuf BJ, Laws RM (eds) Elephant seals. University of California Press, Berkeley, p 310-327

Baechler J, Beck CA, Bowen WD (2002) Dive shapes reveal temporal changes in the foraging behaviour of different age and sex classes of harbour seals (Phoca vitulina). Can J Zool 80:1569-1577

Bengtson JL, Stewart BS (1992) Diving and haulout behavior of crabeater seals in the Weddell Sea, Antarctica, during March 1986. Polar Biol 12:635-644

Bjorge A, Thompson D, Hammond P, Fedak M, Bryant E, Aarefjord H, Roen R, Olsen M (1995) Habitat use and diving behaviour of harbour seals in a coastal archipelago in Norway. In: Blix AS, Walloe L, Ulltang O (eds) Whales, seals, fish and man. Elsevier, Amsterdam, p 211-223

Bowen WD, Tully D, Boness DJ, Bulheier BM, Marshall GJ (2002) Prey-dependent foraging tactics and prey profitability in a marine mammal. Mar Ecol Prog Ser 244:235-245

Castellini MA, Davis RW, Kooyman GL (1992) Annual cycles of diving behavior and ecology of the Weddell seal. Bull Scripps Inst Ocean No. 8. University California Press, Berkeley

Crocker DE, Le Boeuf BJ, Costa DP (1997) Drift diving in female northern elephant seals: implications for food processing. Can J Zool 75(1):27-39

Davis RW, Kanatous SB (1999) Convective oxygen transport and tissue oxygen consumption in Weddell Seals during aerobic dives. J Exp Biol 202:1091-1113

Davis RW, Fuiman LA, Williams TM, Collier SO, Hagey WP, Kanatous SB, Kohin S, Horning M (1999) Hunting behavior of a marine mammal beneath the Antarctic fast ice. Science 283:993-996

Fuiman LA, Davis RW, Williams TM (2002) Behavior of midwater fishes under the Antarctic ice: observations by a predator. Mar Biol 140:815-822

Harcourt RG, Hindell MA, Bell DG, Waas JR (2000) Threedimensional dive profiles of free-ranging Weddell seals. Polar Biol 23:479-487

Heithaus MR, Marshall GJ, Buhleier BM, Dill LM (2001) Employing Crittercam to study habitat use and behavior of large sharks. Mar Ecol Prog Ser 209:307-310

Hindell MA, Slip DJ, Burton HR (1991) The diving behaviour of adult male and female southern elephant seals, Mirounga leonine (Pinnipedia: Phocidae). Aust J Zool 39: 595-619

Hindell MA, Harcourt R, Waas JR, Thompson D (2002) Finescale three-dimensional spatial use by diving, lactating female Weddell seals Leptonychotes weddellii. Mar Ecol Prog Ser 242:275-284

Hooker SK, Boyd IL, Jessop M, Cox O, Blackwell J, Boveng PL, Bengtson JL (2002) Monitoring the prey-field of marine predators: combining digital imaging with data logging tags. Mar Mamm Sci 18(3):680-697

Kooyman GL (1965) Techniques used in measuring diving capacities of Weddell seals. Polar Rec 12(79):391-394

Kooyman GL (1968) An analysis of some behavioral and physiological characteristics related to diving in the Weddell seal. In: Schmitt WL, Llano GA (eds) Antarctic Research Series, Vol. 11, Biology of the Antarctic Seas III. American Geophysical Union, Washington, DC, p 227-261

Kooyman GL, Wahrenbrock EA, Castellini MA, Davis RW, Sinnett EE (1980) Aerobic and anaerobic metabolism during voluntary diving in Weddell seals: evidence of preferred pathways from blood chemistry and behavior. J Comp Physiol 138:335-346

Lavigne DM, Bernholz CD, Ronald K (1977) Functional aspects of pinniped vision. In: Harrison RJ (ed) Functional anatomy of marine mammals. Academic Press, New York, p 135-174

Le Boeuf BJ, Costa DP, Huntley AC, Keldkamp SD (1988) Continuous, deep diving in female northern elephant seals, Mirounga angustirostris. Can J Zool 66:446-458

Le Boeuf BJ, Naito Y, Asaga T, Crocker D, Costa DP (1992) Swim speed in a female northern elephant seal: metabolic and foraging implications. Can J Zool 70:786-795 
Le Boeuf BJ, Crocker DE, Blackwell SB, Morris PA, Thorson $\mathrm{PH}$ (1993) Sex differences in diving and foraging behaviour of northern elephant seals. Symp Zool Lond 66:149-178

Lesage V, Hammill MO, Kovacs KM (1999) Functional classification of harbor seal (Phoca vitulina) dives using depth profiles, swimming velocity, and an index of foraging success. Can J Zool 77(1):74-87

Lythgoe JN, Dartnell HJA (1970) A 'deep sea rhodopsin' in a marine mammals. Nature 227:995-996

Marshall GJ (1998) Crittercam: an animal-borne imaging and data logging system. Mar Tech Soc J 32:11-17

Milligan GW, Cooper MC (1985) An examination of procedures for determining the number of clusters in a data set. Psychometrika 50:159-179

Mitani Y, Sato K, Ito S, Cameron MF, Siniff DB, Naito Y (2003) A method for reconstructing three-dimensional dive profiles of marine mammals using geomagnetic intensity data: results from two lactating Weddell seals. Polar Biol 26:311-317

Nealson KH (1981) Bioluminescence. In: Nealson KH (ed) Current perspectives. Burgess Publishing Company, Minneapolis, MN

Parrish FA, Abernathy K, Marshall GJ, Buhleier BM (2002) Hawaiian monk seals (Monachus schauinslandi) foraging in deep-water coral beds. Mar Mamm Sci 18(1): $244-258$

Ponganis PJ, Van Dam RP, Marshall G, Knower T, Levenson DH (2000) Sub-ice foraging behavior of emperor penguins. J Exp Biol 203:3275-3278

Plotz J, Bornemann H, Knust R, Schroder A, Bester M (2001)
Foraging behavior of Weddell seals, and its ecological implications. Polar Biol 24:901-909

Schreer JF, Testa JW (1995) Statistical classification of diving behavior. Mar Mamm Sci 11(1):85-93

Schreer JF, Testa JW (1996) Classification of Weddell seal diving behavior. Mar Mamm Sci 12(2):227-250

Schreer JF, Kovacs KM, Hines RJO (2001) Comparative diving patterns of pinnipeds and seabirds. Ecol Monogr 71(1): 137-162

Simpkins MA, Kelly BP, Wartzok D (2001a) Three-dimensional movements within individual dives by ringed seals (Phoca hispida). Can J Zool 79:1455-1464

Simpkins MA, Kelly BP, Wartzok D (2001b) Three-dimensional analysis of search behaviour by ringed seals. Anim Behav 62:67-72

Simpkins MA, BP Kelly, Wartzok D (2001c) Three-dimensional diving behaviors of ringed seals (Phoca hispida). Mar Mamm Sci 17(4):909-925

Testa JW (1994) Over-winter movements and diving behavior of female Weddell seals (Leptonychotes weddellii) in the southwestern Ross Sea, Antarctica. Can J Zool 72: $1700-1710$

Wartzok D, Elsner R, Stone H, Kelly BP, Davis RW (1992) Under-ice movements and the sensory basis of hole finding by ringed and Weddell seals. Can J Zool 70(9): 1712-1722

Williams TM, Davis RW, Fuiman LA, Francis J, Le Boeuf BJ, Horning M, Calambokidis J, Croll DA (2000) Sink or swim: strategies for cost-efficient diving by marine mammals. Science 288:133-136

Appendix 1. Variables used to describe Weddell seal Leptonychotes weddellii dives. The far point is the position of the seal at its greatest distance from the hole. Outbound and inbound segments of a dive are separated by the far point. CV: coefficient of variation (defined as SD/mean). Approximate depth of neutral buoyancy (60 m) from Williams et al. (2000). Minimum depth for Pleuragramma antarcticum (160 m) from Fuiman et al. (2002)

\begin{tabular}{|c|c|c|}
\hline $\begin{array}{l}\text { Attribute } \\
\text { Dive segment }\end{array}$ & Variable (code) & Definition (units) \\
\hline \multicolumn{3}{|l|}{ Position } \\
\hline \multirow[t]{6}{*}{ Complete } & Mean depth (DEP_MN) & Mean of all depths recorded during dive (m) \\
\hline & Max. depth (DEP_MX) & Max. depth recorded during dive (m) \\
\hline & Far point depth (FARPNT_DEPTH) & Depth at far point (m) \\
\hline & Far point X (FARPNT_X) & Distance east or west of hole at far point (m) \\
\hline & Far point Y (FARPNT_Y) & Distance north or south of hole at far point (m) \\
\hline & CV depth (DEP_CV) & Variability in depth recorded during dive (CV) \\
\hline \multirow[t]{3}{*}{ Outbound } & Mean depth (OÜTDEP_MN) & Mean of all depths recorded during outbound leg $(\mathrm{m})$ \\
\hline & Max. depth (OUTDEP_MX) & Max. of all depths recorded during outbound leg (m) \\
\hline & CV depth (OUTDEP_CV) & Variability in depth recorded during outbound leg (CV) \\
\hline \multirow[t]{3}{*}{ Inbound } & Mean depth (INDEP_MN) & Mean of all depths recorded during inbound leg (m) \\
\hline & Max. depth (INDEP_MX) & Max. of all depths recorded during inbound leg (m) \\
\hline & CV depth (INDEP_CV) & Variability in depth recorded during inbound leg $(\mathrm{CV})$ \\
\hline \multicolumn{3}{|l|}{ Time } \\
\hline \multirow[t]{4}{*}{ Complete } & Dive duration (DURA) & Total duration of dive (min) \\
\hline & Elapsed time to far point (TIME_FARPT) & Elapsed time from start of dive to far point (min) \\
\hline & Local time at far point (CLOCK_FARPT) & Local time at far point (expressed as a fraction of a day) \\
\hline & Duration below 160 m (DURA_160) & Total time spent below min. depth for Pleuragramma (min) \\
\hline \multirow[t]{2}{*}{ Outbound } & Outbound duration (OUTDURA) & Duration of outbound leg (min) \\
\hline & Duration below 160 m (OUTDURA_160) & $\begin{array}{l}\text { Time spent below min. depth for Pleuragramma during } \\
\text { outbound leg (min) }\end{array}$ \\
\hline \multirow[t]{2}{*}{ Inbound } & Inbound duration (INDURA) & Duration of inbound leg (min) \\
\hline & Duration below 160 m (INDURA_160) & $\begin{array}{l}\text { Time spent below min. depth for Pleuragramma during } \\
\text { inbound leg (min) }\end{array}$ \\
\hline
\end{tabular}


Appendix 1 (continued)

\begin{tabular}{|c|c|c|}
\hline $\begin{array}{l}\text { Attribute } \\
\text { Dive segment }\end{array}$ & Variable (code) & Definition (units) \\
\hline \multicolumn{3}{|l|}{ Distance } \\
\hline \multirow[t]{2}{*}{ Complete } & Total distance traveled (DIST_TOT) & Total distance along dive path (m) \\
\hline & Max. distance from hole (FARPNT_DIST) & Net 3-dimensional displacement from hole to far point (m) \\
\hline Outbound & Distance traveled (OUTDIST_TOT) & Distance along dive path during outbound leg (m) \\
\hline Inbound & Distance traveled (INDIST_TOT) & Distance along dive path during inbound leg $(\mathrm{m})$ \\
\hline \multicolumn{3}{|l|}{ Speed } \\
\hline \multirow[t]{3}{*}{ Complete } & Mean speed (SPEED_MN) & Mean speed during dive $\left(\mathrm{m} \mathrm{s}^{-1}\right)$ \\
\hline & Max. speed (SPEED_MX) & Max. speed during dive $\left(\mathrm{m} \mathrm{s}^{-1}\right)$ \\
\hline & CV speed (SPEED_CV) & Variability in speed during dive (CV) \\
\hline \multirow[t]{3}{*}{ Outbound } & Mean speed (OUTSPEED_MN) & Mean speed during outbound leg of dive $\left(\mathrm{m} \mathrm{s}^{-1}\right)$ \\
\hline & Max. speed (OUTSPEED_MX) & Max. speed during outbound leg of dive $\left(\mathrm{m} \mathrm{s}^{-1}\right)$ \\
\hline & CV speed (OUTSPEED_C̄V) & Variability in speed during outbound leg of dive (CV) \\
\hline \multirow{3}{*}{ Inbound } & Mean speed (INSPEED_MN) & Mean speed during inbound leg of dive $\left(\mathrm{m} \mathrm{s}^{-1}\right)$ \\
\hline & Max. speed (INSPEED_MX) & Max. speed during inbound leg of dive $\left(\mathrm{m} \mathrm{s}^{-1}\right)$ \\
\hline & CV speed (INSPEED_CV) & Variability in speed during inbound leg of dive (CV) \\
\hline \multicolumn{3}{|l|}{ Angle } \\
\hline \multirow[t]{8}{*}{ Outbound } & Mean bearing (OUTBRNG_MN) & Mean direction of dive path during outbound leg (degrees) \\
\hline & Mean vertical angle (OUTVANG_MN) & Mean descent angle from hole to far point (degrees) \\
\hline & $\begin{array}{l}\text { Initial descent angle }(0-60 \mathrm{~m}) \\
\text { (OUTVANG1_MN) }\end{array}$ & $\begin{array}{l}\text { Mean descent angle from hole to approximate depth of } \\
\text { neutral buoyancy ( } 60 \mathrm{~m} \text { ) (degrees) }\end{array}$ \\
\hline & $\begin{array}{l}\text { Secondary descent angle }(60-100 \mathrm{~m}) \\
\text { (OUTVANG2_MN) }\end{array}$ & $\begin{array}{l}\text { Mean descent angle from approximate depth of neutral } \\
\text { buoyancy }(60 \mathrm{~m}) \text { to } 100 \mathrm{~m} \text { deep (degrees) }\end{array}$ \\
\hline & Bearing variation (OUTBRNG_R) & $\begin{array}{l}\text { Length of mean vector of bearings during outbound leg, } \\
\text { a measure of angular concentration (ranges from } 0 \text { to } 1 \text { ) }\end{array}$ \\
\hline & CV vertical angle (OUTVANG_CV) & Variability in descent angle (CV) \\
\hline & CV initial descent angle (OUTVANG1_CV) & $\begin{array}{l}\text { Variability in descent angle from hole to approximate depth } \\
\text { of neutral buoyancy }(60 \mathrm{~m})(\mathrm{CV})\end{array}$ \\
\hline & $\begin{array}{l}\text { CV secondary descent angle } \\
\text { (OUTVANG2_CV) }\end{array}$ & $\begin{array}{l}\text { Variability in descent angle from approximate depth of } \\
\text { neutral buoyancy }(60 \mathrm{~m}) \text { to } 100 \mathrm{~m} \text { deep (CV) }\end{array}$ \\
\hline \multirow[t]{8}{*}{ Inbound } & Mean bearing (INBRNG_MN) & Mean direction of dive path during inbound leg (degrees) \\
\hline & Mean vertical angle (INVANG_MN) & Mean ascent angle from far point to hole (degrees) \\
\hline & $\begin{array}{l}\text { Final ascent angle (above } 60 \mathrm{~m} \text { ) } \\
\text { (INVANG1_MN) }\end{array}$ & $\begin{array}{l}\text { Mean ascent angle from approximate depth of neutral } \\
\text { buoyancy }(60 \mathrm{~m}) \text { to hole (degrees) }\end{array}$ \\
\hline & $\begin{array}{l}\text { Secondary ascent angle }(100-60 \mathrm{~m}) \\
\text { (INVANG2_MN) }\end{array}$ & $\begin{array}{l}\text { Mean ascent angle from } 100 \mathrm{~m} \text { deep to approximate depth } \\
\text { of neutral buoyancy }(60 \mathrm{~m}) \text { (degrees) }\end{array}$ \\
\hline & Bearing variation (INBRNG_R) & $\begin{array}{l}\text { Length of mean vector of bearings during inbound leg, a } \\
\text { measure of angular concentration (ranges from } 0 \text { to } 1 \text { ) }\end{array}$ \\
\hline & CV vertical angle (INVANG_CV) & Variability in ascent angle (CV) \\
\hline & CV final ascent angle (INVANG1_CV) & $\begin{array}{l}\text { Variability in ascent angle from approximate depth of } \\
\text { neutral buoyancy }(60 \mathrm{~m}) \text { to hole }(\mathrm{CV})\end{array}$ \\
\hline & CV secondary ascent angle (INVANG2_CV) & $\begin{array}{l}\text { Variability in ascent angle from } 100 \mathrm{~m} \text { deep to approximate } \\
\text { depth of neutral buoyancy }(60 \mathrm{~m})(\mathrm{CV})\end{array}$ \\
\hline \multicolumn{3}{|l|}{ Linearity } \\
\hline \multirow[t]{3}{*}{ Complete } & Path linearity (XYZ_NGDR) & $\begin{array}{l}2 \times \text { distance from hole to far point (FARPNT_DIST) divided } \\
\text { by total distance traveled (DIST_TOT) }\end{array}$ \\
\hline & Horizontal path linearity (XY_NGDR) & $\begin{array}{l}2 \times \text { distance in horizontal plane from hole to far point } \\
\text { divided by total distance traveled in the horizontal plane }\end{array}$ \\
\hline & Vertical path linearity (Z_NGDR) & $2 \times$ max. depth divided by sum of all depths recorded \\
\hline \multirow[t]{3}{*}{ Outbound } & Path linearity (OUTXYZ_NGDR) & $\begin{array}{l}\text { Net 3D displacement (FARPNT_DIST) divided by gross } \\
\text { displacement during outbound leg (OUTDIST_TOT) }\end{array}$ \\
\hline & Horizontal path linearity (OUTXY_NGDR) & $\begin{array}{l}\text { Net displacement in horizontal plane divided by gross } \\
\text { displacement in horizontal plane during outbound leg }\end{array}$ \\
\hline & Vertical path linearity (OUTZ_NGDR) & $\begin{array}{l}\text { Net to gross displacement in depth during inbound leg, } \\
\text { calculated as } 1 \text { - (OUTXYZ_NGDR-OUTXY_NGDR) }\end{array}$ \\
\hline \multirow[t]{3}{*}{ Inbound } & Path linearity (INXYZ_NGDR) & $\begin{array}{l}\text { Net 3D displacement (FARPNT_DIST) divided by gross } \\
\text { displacement during inbound leg (INDIST_TOT) }\end{array}$ \\
\hline & Horizontal path linearity (INXY_NGDR) & $\begin{array}{l}\text { Net displacement in horizontal plane divided by gross } \\
\text { displacement in horizontal plane during inbound leg }\end{array}$ \\
\hline & Vertical path linearity (INZ_NGDR) & $\begin{array}{l}\text { Net to gross displacement in depth during inbound leg } \\
\text { calculated as } 1 \text { - (INXYZ_NGDR-INXY_NGDR) }\end{array}$ \\
\hline
\end{tabular}

